\title{
Diffusion of Elements in Porcelain into Titanium Oxide
}

\author{
Takao HANAWA, Masayuki KON, Shoji OHKAWA ${ }^{1}$ and Kenzo ASAOKA \\ Department of Dental Engsineering, School of Dentistry, Tokushima University, \\ 3 Kuramoto-cho, Tokushima 770, Japan \\ ${ }^{1}$ Department of Dental Materials and Engineering, Hokkaido University School of Dentistry, \\ Kita 13 Nishi 7, Kita-ku, Sapporo 060, Japan
}

Received July 18, 1994/Accepted October 19, 1994

\begin{abstract}
The diffusion of elements of commercial porcelain for titanium into titanium oxide during heating was investigated. Titanium was deposited on three kinds of disk-shaped porcelains by vacuum-vaporization and the porcelains were then heated. A thin titanium oxide film was formed on the porcelains by the heating. $\mathrm{X}$-ray photoelectron spectroscopy was used to characterize the surfaces of the porcelains with and without titanium oxide. Only sodium, potassium, and barium diffused into titanium oxide during heating, where they formed a complex oxide with titanium. The diffusion of these elements may be involved in the bonding of porcelain to titanium.
\end{abstract}

Key words: Porcelain, Titanium, XPS

\section{INTRODUCTION}

Various casting processes have been developed for titanium in dentistry, the some of which are used commercially. From the success of these casting procedures, the bonding of porcelain to titanium has been attempted, and several porcelains for titanium are now available commercially. The bonding strength is important not only for the porcelain bonding technique to titanium but also for that to other alloys. It is primarily governed by a reaction layer existing between porcelain and titanium that is formed by the mutual diffusion of elements. In this regard, porcelain-fused-to-titanium systems have been studied. Togaya $e t$ al. ${ }^{1)}$ investigated the feasibility of using titanium in a metal-porcelain system, and they demonstrated the advantages of the system with regard to the thermal expansion and mechanical properties of titanium at high temperatures. Adachi et al. ${ }^{2)}$ reported the relationship between the oxidation of titanium and $\mathrm{Ti}-6 \mathrm{Al}-4 \mathrm{~V}$ and bonding strength; bonding strength is low when the thickness of the oxide layer reaches $1 \mu \mathrm{m}$. Kimura et $a$ al $^{3)}$ also examined the effects of oxidation on porcelain-titanium interface reactions and bonding strength. They found a layer at the interface that is formed by the diffusion of titanium into the porcelain. Nagayama et al.4) characterized the interface between titanium and porcelain using electron probe microanalysis (EPMA) and X-ray photoelectron spectroscopy (XPS). They revealed that titanium atoms diffused into the porcelain and that a reaction layer was formed, possibly corresponding to that found by Kimura $e t a l .^{3)}$ For the formation of the reaction layer, titanium atoms apparently diffuse into the porcelain during the firing process because only commercial pure titanium is used in porcelain-fused-to-titanium systems at present. 
The three studies described above ${ }^{1-3)}$ show that titanium is easily oxidized during the firing process. In a porcelain-fused-to-titanium system, Oshida and $\mathrm{Hashem}^{5)}$ examined the oxidation kinetics of titanium during the porcelain firing process. Diffusion of elements in porcelain into the titanium, $i$. e. titanium oxide, during firing is also significant in porcelain -fused-to-titanium systems because bonding occurs between the two components by the mutual diffusion of elements. However, it is predicted that observation of the diffusion layer should be difficult by EPMA because the amount of elements diffused into titanium is small. In fact, no one has yet examined this phenomenon. The surface analysis technique seems to be suitable for the characterization of the diffusion layer. Ohuchi and Kohyama ${ }^{6}$ applied a surface analysis technique to the characterization of the interface between ceramics and metal, and reported changes in the chemical states of elements in both components. They reproduced the interface between ceramics and titanium on a surface by a vaporization technique.

In this study, we deposited a thin titanium layer on commercial porcelain for titanium by vaporization and then heated the specimen. Diffusion of elements in the porcelain and the oxidation of titanium should occur during this process. The surface was analyzed using XPS to characterize the diffusion of elements in porcelain into the titanium, and to determine the changes in the chemical states of these elements within titanium layer.

\section{MATERIALS AND METHODS}

Three kinds of commercial porcelains, $\mathrm{A}^{*}, \mathrm{~B} * *$, and $\mathrm{C}^{\sharp}$, for titanium, which directly contact titanium, were used in this study. Porcelains $A$ and $B$ were supplied in powder form and $C$ was supplied as a pasty powder. Porcelains A and B were mixed with deionized water. All porcelain powders were formed into disks with a size of $15 \mathrm{~mm}$ in diameter and $2 \mathrm{~mm}$ in height on platinum foil. Powder compacts were fired according to each manufacturer's recommended firing schedule in a porcelain furnace\#.

After firing, titanium was deposited on the fired porcelains by vaporization using a vacuum vaporizer ${ }^{\circledR}$. Two thicknesses of titanium were deposited with the same thickness being used on each porcelain. The porcelains were located on a slide glass when the titanium was deposited; $i$. e. both the deposit area and non-deposit area were present on the slide glass. However, we could not control the exact thickness of deposits because there was no thickness meter attached. Therefore, the thickness of deposition on the slide glass was measured using a surface roughness analyzer ${ }^{\circledR}$ a and ellipsometer\$. We designated the thinner deposition as "low-Ti" and the thicker deposition as "high-Ti."

To react the porcelains with titanium and oxidize titanium, the porcelain specimens on which titanium was deposited were reheated from $500^{\circ} \mathrm{C}$ to $750^{\circ} \mathrm{C}$ with a heating rate of

* Bonding, TITAN, Noritake, Nagoya, Japan

* * Opaque $\mathrm{A}_{3} \mathrm{O}$, Titan Bond, Ohara, Osaka, Japan

\# Haft-bond, Duceratin Titankeramik, Ducera, Germany

\# Vacuum Furnace, Shofu, Tokyo, Japan

@ HUS-4, Hitachi, Tokyo, Japan

@ @ SE-3C, Kosaka Laboratory, Tokyo, Japan

\$ DV-36, Mizojiri Kogaku, Tokyo, Japan 
$50^{\circ} \mathrm{C} / \mathrm{min}$ and cooled to ambient temperature in air. After cooling, the specimens were ultrasonically washed in acetone and ethanol for 15 min each. For comparison, porcelain specimens without titanium deposition "non- $\mathrm{Ti}$ " were prepared according to the methods described above.

XPS was performed using an electron spectrometer\$. All binding energies given in this paper are relative to the Fermi level and all spectra were obtained with the MgK $\alpha$ line (energy $1253.6 \mathrm{eV}$, voltage $15 \mathrm{kV}$, and current $20 \mathrm{~mA}$ ). The beam size of the $\mathrm{X}$-ray was 10 $\mathrm{mm} \times 6 \mathrm{~mm}$ in an ellipse. The electron energy analyzer was operated in the constant analyzer energy mode at a pass energy of $20 \mathrm{eV}$. The binding energies measured were calibrated with those of $\mathrm{Au}_{4} \mathrm{f}_{7 / 2}(84.0 \mathrm{eV})$ and $\mathrm{Cu} 2 \mathrm{p}_{3 / 2}(932.7 \mathrm{eV})$ taken from the report by Anthony and Seah ${ }^{7}$. Resolution with full width at half-maximum (FWHM) of the Au4f $\mathrm{f}_{7 / 2}$ peak was $1.1 \mathrm{eV}$ under our experimental conditions, and the binding energies were measured with an accuracy of $0.1 \mathrm{eV}$. The base pressure was $6 \times 10^{-8} \mathrm{~Pa}$ during the spectral acquisitions. The escape angle for photoelectron detection was $15^{\circ}\left(75^{\circ}\right.$ from the surface of the specimen). The relative concentrations of elements were calculated, assuming the gross amount of all elements except carbon detected using XPS was 100 atomic percent. The quantification methods are described elsewhere ${ }^{8,9)}$. The quantification error in the calculations was estimated to be $\pm 5-30 \%$.

\section{RESULTS}

The thicknesses of the titanium depositions determined by surface roughness analysis and ellipsometry are summarized in Table 1 . We could not determine the thickness of deposit on low-Ti specimens using surface roughness analysis because the titanium deposit was too thin; $i$. e. the step size between the deposit area and the non-deposit area on the slide glass was too small. In high-Ti specimens, the thicknesses measured by both methods were almost the same.

In non- $\mathrm{Ti}$ specimens of all porcelains, boron, carbon, oxygen, sodium, aluminum, silicon, potassium, zinc, and tin were detected using XPS, as summarized in Table 2. Calcium was detected in porcelains $\mathrm{A}$ and $\mathrm{B}$, zirconium was detected in porcelain $\mathrm{B}$, and barium was detected in $\mathrm{A}$ and $\mathrm{C}$. Titanium was detected in $\mathrm{B}$ and $\mathrm{C}$ non-Ti specimens, regardless of the lack of titanium deposition. On the other hand, in high-Ti specimens, carbon, oxygen, sodium, potassium, and titanium were detected in all porcelains, and barium was detected in $\mathrm{A}$ and C. The Cls XPS spectrum obtained from the non-Ti specimen of porcelain A is shown

Table 1 Thickness of titanium deposited on porcelains by vaporization

\begin{tabular}{lcc}
\hline \multirow{2}{*}{ Method } & \multicolumn{2}{c}{ Thickness of deposit $(\mathrm{nm})$} \\
\cline { 2 - 3 } & Low-Ti & High-Ti \\
\hline Surface-roughness analysis & - & 400 \\
Ellipsometry & 4.2 & 425.7 \\
\hline
\end{tabular}

$\$ \quad$ ESCALAB MK-II, Vacuum Generator Scientific, UK 
Table 2 Relative concentrations of elements in dental porcelains with and without Ti-deposits determined using XPS

\begin{tabular}{|c|c|c|c|c|}
\hline \multirow{2}{*}{\multicolumn{2}{|c|}{ Element }} & \multicolumn{3}{|c|}{ Relative concentration (at.\%) } \\
\hline & & \multirow{2}{*}{$\begin{array}{c}\text { Non- } \mathrm{Ti} \\
51.4\end{array}$} & \multirow{2}{*}{$\frac{\text { Low-Ti }}{53.3(37.8)}$} & \multirow{2}{*}{$\begin{array}{r}\text { High-Ti } \\
66.4(51.8)\end{array}$} \\
\hline A & $\mathrm{O}$ & & & \\
\hline & $\mathrm{Ti}$ & 0.0 & 16.2 & 29.1 \\
\hline & B & 5.7 & 7.2 & 0.0 \\
\hline & $\mathrm{Na}$ & 1.4 & 2.3 & 2.8 \\
\hline & $\mathrm{Al}$ & 5.2 & 2.1 & 0.0 \\
\hline & $\mathrm{Si}$ & 30.0 & 9.5 & 0.0 \\
\hline & $\mathrm{K}$ & 3.4 & 1.0 & 1.4 \\
\hline & $\mathrm{Ca}$ & 0.2 & 0.4 & 0.0 \\
\hline & $\mathrm{Zn}$ & 0.1 & 0.1 & 0.0 \\
\hline & $\mathrm{Zr}$ & 0.0 & 0.0 & 0.0 \\
\hline & $\mathrm{Sn}$ & 0.4 & 0.2 & 0.0 \\
\hline & $\mathrm{Ba}$ & 2.2 & 7.7 & 0.3 \\
\hline \multirow[t]{12}{*}{$\mathrm{B}$} & $\mathrm{O}$ & 48.6 & $56.8(35.2)$ & $65.9(57.3)$ \\
\hline & $\mathrm{Ti}$ & 0.3 & 21.3 & 33.1 \\
\hline & B & 3.7 & 2.9 & 0.0 \\
\hline & $\mathrm{Na}$ & 1.0 & 1.2 & 0.1 \\
\hline & $\mathrm{Al}$ & 7.9 & 3.4 & 0.0 \\
\hline & $\mathrm{Si}$ & 33.2 & 11.7 & 0.0 \\
\hline & $\mathrm{K}$ & 3.2 & 0.5 & 0.9 \\
\hline & $\mathrm{Ca}$ & 0.7 & 1.1 & 0.0 \\
\hline & $\mathrm{Zn}$ & 0.1 & 0.1 & 0.0 \\
\hline & $\mathrm{Zr}$ & 0.9 & 0.7 & 0.0 \\
\hline & $\mathrm{Sn}$ & 0.4 & 0.3 & 0.0 \\
\hline & $\mathrm{Ba}$ & 0.0 & 0.0 & 0.0 \\
\hline \multirow[t]{12}{*}{$\mathrm{C}$} & $\mathrm{O}$ & 47.7 & 51.3 & $64.8(48.6)$ \\
\hline & $\mathrm{Ti}$ & 0.3 & 1.9 & 29.5 \\
\hline & B & 3.9 & 3.9 & 0.0 \\
\hline & $\mathrm{Na}$ & 1.3 & 2.1 & 3.2 \\
\hline & $\mathrm{Al}$ & 4.3 & 3.4 & 0.0 \\
\hline & $\mathrm{Si}$ & 38.0 & 33.6 & 0.0 \\
\hline & $\mathrm{K}$ & 4.2 & 3.3 & 2.4 \\
\hline & $\mathrm{Ca}$ & 0.0 & 0.0 & 0.0 \\
\hline & $\mathrm{Zn}$ & 0.1 & 0.1 & 0.0 \\
\hline & $\mathrm{Zr}$ & 0.0 & 0.0 & 0.0 \\
\hline & $\mathrm{Sn}$ & 0.1 & 0.1 & 0.0 \\
\hline & $\mathrm{Ba}$ & 0.1 & 0.3 & 0.1 \\
\hline
\end{tabular}

The values in parentheses represent the concentration of oxygen originating from oxide-state oxygen and not that originating from hydroxyl groups, hydroxide, hydrate, or adsorbed water.

in Fig. 1. The spectrum contained peaks of carbon originating from a residual organic compound in the bonding agent after firing. These peaks were observed in all specimens under all conditions.

The relative concentrations of elements, assuming the gross amount of the elements detected using XPS except carbon to be 100 atomic percent, are summarized in Table 2. 


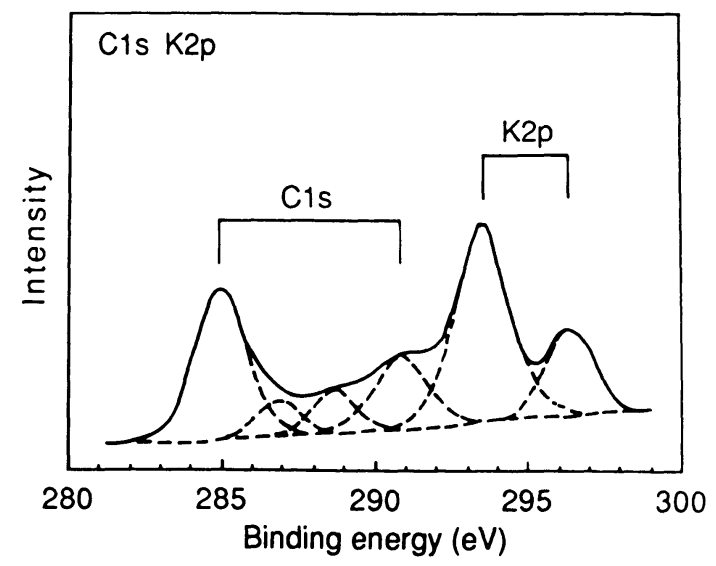

Fig. 1 XPS spectra of $\mathrm{Cls}$ and $\mathrm{K} 2 \mathrm{p}$ regions obtained from porcelain $A$ without titanium-deposition. Four component spectra of $\mathrm{Cls}$, represented by dashed lines, originated mainly from $\mathrm{CH}_{2}$ and phenyl radical, $\mathrm{C}-\mathrm{O}$ bond, $\mathrm{C}=\mathrm{O}$ bond, and $\mathrm{COO}^{-}$in this order from lower energy site $^{10)}$. K2p spectrum contained $\mathrm{K} 2 \mathrm{p}_{3 / 2}$ and $\mathrm{K} 2 \mathrm{p}_{1 / 2}$.

The Ols spectrum should be decomposed into component spectra originating from oxides, hydroxyl groups and/or hydroxides, and hydrate and/or adsorbed water ${ }^{11)}$. Values in parentheses represent the concentrations of oxide-state oxygen, which does not include those of hydroxyl groups and adsorbed water. Moisture in air is easily adsorbed as hydroxyl groups by the surface of titanium oxide ${ }^{12}$. In non-Ti specimens, the concentration of silicon, the main component of the porcelains, was $30-38 \%$, representing most abundant element except for oxygen. The concentration of boron in the porcelain used in the study was much higher than that in conventional porcelains ${ }^{13}$. The concentrations of boron, aluminum, silicon, calcium, zinc, zirconium, and tin decreased with the increases in the amount of titanium deposited, and these elements were undetectable in high-Ti specimens. However, sodium, potassium, and barium, along with oxygen and titanium, were still detected even in high- $\mathrm{Ti}$ specimens. The concentration of oxygen was almost constant when only oxidestate oxygen was watched. The amount of titanium increased with the increases in the amount of titanium deposited.

Core-level binding energies of elements in the specimens are summarized in Table 3. Those of boron, sodium, aluminum, silicon, potassium, calcium, titanium, zinc, zirconium, tin, and barium were in the oxide state as determined from published binding energies ${ }^{10,14}$. The titanium detected in non- $\mathrm{Ti}$ specimens of porcelains $\mathrm{B}$ and $\mathrm{C}$ existed as $\mathrm{TiO}_{2}$. Ti2p spectra obtained from high-Ti specimens are shown in Fig. 2. Ti2 $\mathrm{p}_{3 / 2}$ spectra were symmetrical, and the FWHMs of the spectra were approximately $1.4 \mathrm{eV}$, indicating that the titanium consisted of a single phase. The binding energy of the spectra revealed that titanium atoms exist in an oxide state whose valences were in a range of 3-4, determined by comparison with published binding energies ${ }^{10,14,15}$. According to Fig. 2, the valences of titanium in all porce- 
Table 3 Core-level binding energies of XPS spectra obtained from dental porcelains with and without $\mathrm{Ti}$-deposits

\begin{tabular}{|c|c|c|c|c|}
\hline \multirow{2}{*}{\multicolumn{2}{|c|}{$\begin{array}{l}\text { Element and } \\
\text { level }\end{array}$}} & \multicolumn{3}{|c|}{ Binding energy $(\mathrm{eV})$} \\
\hline & & Non-Ti & Low-Ti & High-Ti \\
\hline & $\mathrm{A} 12 \mathrm{p}$ & 74.5 & $(74.5)$ & - \\
\hline & $\mathrm{Si} 2 \mathrm{p}$ & 102.8 & 101.8 & - \\
\hline & $\mathrm{Zr} 3 \mathrm{~d}_{5 / 2}$ & - & - & - \\
\hline & Bls & 192.6 & $(192.2)$ & - \\
\hline & Cls & 285.0 & 285.0 & 285.0 \\
\hline & $\mathrm{K} 2 \mathrm{p}_{3 / 2}$ & 293.4 & 292.7 & 292.3 \\
\hline & $\mathrm{Ca} 2 \mathrm{p}_{3 / 2}$ & $(346.9)$ & $(346.4)$ & - \\
\hline & $\mathrm{Ti} 2 \mathrm{p}_{3 / 2}$ & - & 457.3 & 458.2 \\
\hline & Ols* & 531.5 & 529.5 & 529.7 \\
\hline & $\mathrm{Ba} \mathrm{d}_{5 / 2}$ & 780.1 & 779.3 & 775.4 \\
\hline & $\mathrm{Zn} 2 \mathrm{p}_{3 / 2}$ & $(1021.5)$ & $(1021.4)$ & - \\
\hline & Nals & 1071.7 & 1071.3 & 1071.5 \\
\hline \multirow[t]{12}{*}{ B } & A12p & 74.4 & $(74.3)$ & - \\
\hline & $\mathrm{Si} 2 \mathrm{p}$ & 102.5 & 102.4 & - \\
\hline & $\mathrm{Zr} \mathrm{d}_{5 / 2}$ & 183.0 & 182.8 & - \\
\hline & Bls & 192.7 & $(192.2)$ & - \\
\hline & $\mathrm{Cls}$ & 285.0 & 285.0 & 285.0 \\
\hline & $\mathrm{K} 2 \mathrm{p}_{3 / 2}$ & 293.6 & 292.9 & 292.9 \\
\hline & $\mathrm{Ca} 2 \mathrm{p}_{3 / 2}$ & 347.3 & 347.0 & - \\
\hline & $\mathrm{Ti} 2 \mathrm{p}_{3 / 2}$ & 459.0 & 457.0 & 458.4 \\
\hline & Ols* & 531.3 & 529.8 & 529.8 \\
\hline & $\mathrm{Ba} \mathrm{d}_{5 / 2}$ & - & - & - \\
\hline & $\mathrm{Zn} 2 \mathrm{p}_{3 / 2}$ & $(1022.2)$ & $(1021.6)$ & - \\
\hline & Nals & 1072.3 & 1071.6 & 1071.7 \\
\hline \multirow[t]{12}{*}{$\mathrm{C}$} & A12p & $(74.5)$ & $(74.2)$ & - \\
\hline & Si2p & 103.0 & 102.5 & - \\
\hline & $\mathrm{Zr} 3 \mathrm{~d}_{5 / 2}$ & - & - & - \\
\hline & Bls & 193.0 & (192.6) & - \\
\hline & $\mathrm{Cls}$ & 285.0 & 285.0 & 285.0 \\
\hline & $\mathrm{K} 2 \mathrm{p}_{3 / 2}$ & 293.6 & 293.2 & 292.4 \\
\hline & $\mathrm{Ca} 2 \mathrm{p}_{3 / 2}$ & - & - & - \\
\hline & Ti2 $\mathrm{p}_{3 / 2}$ & 458.7 & 458.8 & 458.3 \\
\hline & Ols* & 532.2 & 532.1 & 529.7 \\
\hline & $\mathrm{Ba} \mathrm{d}_{5 / 2}$ & 780.2 & 780.0 & 779.4 \\
\hline & $\mathrm{Zn} 2 \mathrm{p}_{3 / 2}$ & (1021.8) & (1022.3) & - \\
\hline & Nals & 1072.0 & 1072.0 & 1071.6 \\
\hline
\end{tabular}

* The largest spectrum

The values in parentheses may not be accurate because the intensity of the spectrum was small and determination of the binding energy was difficult.

lains were approximately 3.8. Ols spectra obtained from non-Ti and high-Ti specimens of porcelain $\mathrm{C}$ are shown in Fig. 3. The spectra of non-Ti specimens contained several peaks originating from oxides, while those of high-Ti specimens indicated a single oxide with hydroxyl groups and adsorbed water. 


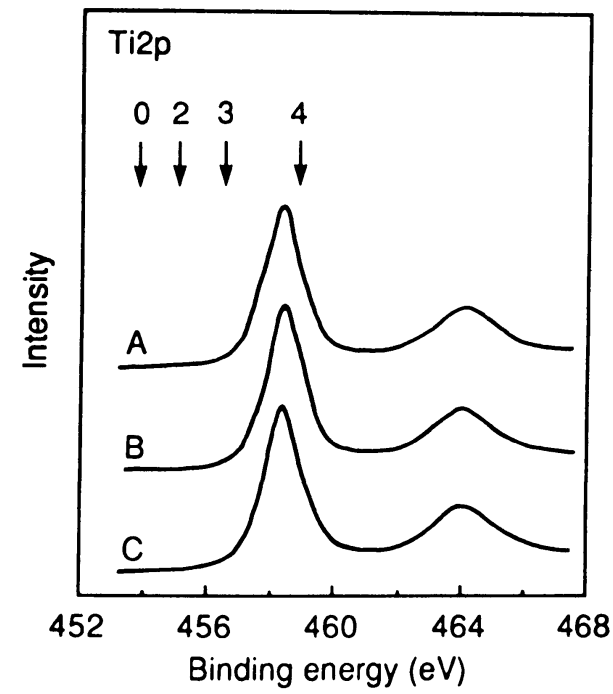

Fig. 2 Ti2p XPS spectra obtained from porcelains $\mathrm{A}, \mathrm{B}$, and $\mathrm{C}$. The binding energy values in each valence of titanium are shown by the arrows.

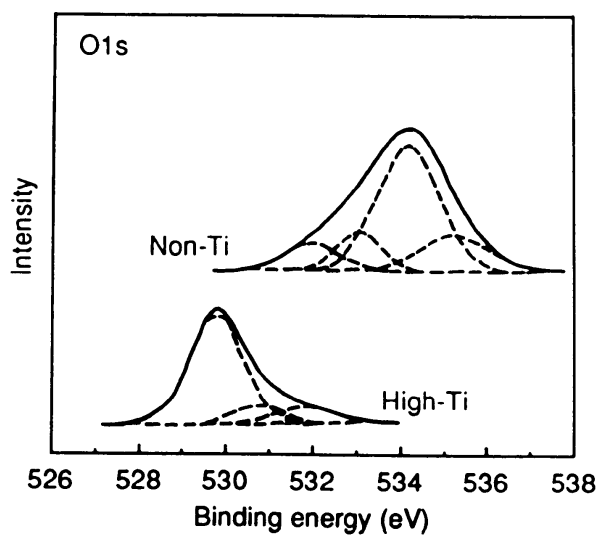

Fig. 3 Ols XPS spectra obtained from porcelain $\mathrm{C}$ without titanium deposition as non-Ti and with titanium deposition as high-Ti.

\section{DISCUSSION}

Titanium in low-Ti specimens may exist as islands on porcelains because the amount of titanium deposited was small, whereas that deposited on high-Ti specimens possibly existed as a uniform film. Titanium was transformed to titanium oxide during heating. However, the morphology did not change after the transformation. The thickness of deposit layers changed during the transformation, although the relative thicknesses of low-Ti and high-Ti 
did not change. The morphology of titanium oxide on porcelain is shown in Fig. 4. The figure also presents the relationship between the thickness of the deposit and the detection depth of XPS. As shown in the figure, all photoelectrons detected from non-Ti specimens on which titanium oxide was absent originated from the porcelain. When titanium was once deposited or when titanium oxide was formed on the porcelain, photoelectrons originated from both the porcelain and titanium oxide, regardless of whether the oxide formed a uniform film or islands. Photoelectrons from the porcelains were no longer detected when the amount of deposition of titanium, $i$. e. the thickness of titanium, increased. Most of the elements in the porcelains were not detected in high- $\mathrm{Ti}$ specimens, indicating that photoelectrons from the porcelains were blocked by deposition of a thicker layer of titanium.

The larger amount of boron compared with conventional porcelain was due to the boron oxide added to reduce thermal expansion ${ }^{16)}$ because the coefficient of thermal expansion of titanium is smaller than that of gold alloys and nickel-chromium alloys ${ }^{17}$. In addition, the increase in proportion of boron oxide causes a decrease in temperature of fusion and increases heat-shock resistance ${ }^{16}$. The amounts of boron, aluminum, silicon, calcium, zinc, zirconium, and tin decreased with increasing deposition of titanium, and these elements were not detected in high-Ti specimens; $i$. e. these elements were not contained in the titanium oxide. On the other hand, sodium, potassium, and barium were still detected even in high-Ti specimens, indicating that these elements were contained in the titanium oxide. As shown in Fig. 3, the Ols spectra of non-Ti specimens were a mixture of component spectra originating from several oxide states. These oxide states apparently originated from the components of the porcelain because only elements of porcelain were detected in non- $\mathrm{Ti}$ specimens. However, the Ols spectra from high-Ti specimens revealed the existence of a single oxide, indicating that the titanium oxide layer mainly consisted of a single composi-

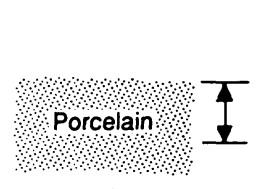

a

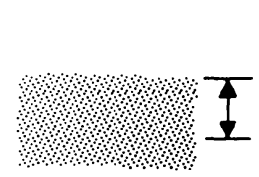

d

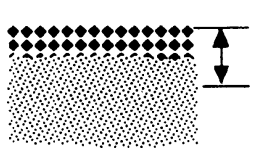

b

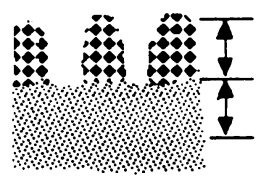

e

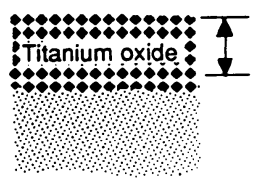

C

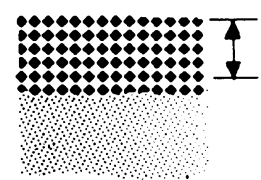

f

Fig. 4 Schematic model of the titanium oxide on porcelain in cases in which titanium oxide formed a layer $(a, b$, and c) and islands (d, e, and f) in a thin deposit, with detection depth by XPS shown by arrow ranges. a and $\mathrm{d}$ : porcelain without titanium deposit. $\mathrm{b}$ and $\mathrm{e}$ : titanium oxide formed a layer or islands on the porcelain by a small amount of titanium deposition. $\mathrm{c}$ and $\mathrm{f}$ : a thick layer of titanium oxide was formed with deposition of a large amount of titanium. 
tion. Therefore, sodium, potassium, and barium formed a complex oxide with titanium in the titanium oxide layer. That is, the single oxides of sodium, potassium, and barium were hardly mixed with the titanium oxide layer.

$\mathrm{Ti} 2 \mathrm{p}_{3 / 2}$ spectra indicated that titanium in the titanium oxide layer existed in an intermediate state between trivalent and tetravalent forms as described above. Calculating the composition of the titanium oxide according to the concentrations of titanium and oxygen in the oxide state in high- $\mathrm{Ti}$ specimens, the compositions were as follows : $\mathrm{Ti}_{3} \mathrm{O}_{5}$ in porcelain A, $\mathrm{Ti}_{7} \mathrm{O}_{12}$ in $\mathrm{B}$, and $\mathrm{Ti}_{5} \mathrm{O}_{8}$ in $\mathrm{C}$. The valences of titanium in these oxides were $3.3,3.4$, and 3.2 , respectively. On the other hand, the valence was estimated as 3.8 in the oxides from Fig. 2 and Table 3. This discrepancy may have been caused by an error in quantification. In any case, the titanium oxide layer mainly consisted of a titanium oxide whose valence was between trivalent and tetravalent and contained small amounts of sodium, potassium, and barium. Sodium, potassium, and barium exist as a complex oxide with titanium because porcelain was coated only with single oxide species as mentioned above. The valence will change with heating temperature and time, and eventually approach the tetravalent state after heating for a long time at a high temperature.

There was a titanium oxide layer between the titanium and porcelain at the bonding interface. Sodium, potassium, and barium were distributed near the interface or throughout the whole oxide layer. The diffusion of sodium, potassium, and barium may be involved in the bonding of titanium to porcelain.

Only sodium, potassium, and barium were detected from the titanium oxide layer. These elements are alkaline metals or alkaline earth metal, and their oxides may easily diffuse into the titanium oxide forming a complex oxide. However, calcium, an alkaline earth metal, existing in porcelain, was not detected from the titanium oxide possibly because the amount of calcium in the porcelains was much less than those of sodium, potassium, and barium. The free energies for the formation of the titanates of these elements are lower than those of the oxides of the elements at $25^{\circ} \mathrm{C}^{18)}$. The diffusion of these elements into titanium (oxide) in this study may be easier than into titanium oxide formed during the actual firing.

In this study, in the interface between titanium oxide and porcelain, the titanium side of the interface was analyzed. However, it was impossible to analyze the porcelain side by this method.

\section{CONCLUSIONS}

Only sodium, potassium, and barium in commercial porcelain for titanium diffused into the titanium during heating. After heating, the titanium oxide layer mainly consisted of titanium oxide whose valence was between trivalent and tetravalent and contained small amounts of sodium, potassium, and barium. These elements formed a complex oxide with titanium. 


\section{ACKNOWLEDGMENTS}

We thank Dr. Kiyoko Ban, president of Cusp Dental Supply Co., Ltd., for her assistance in this study.

\section{REFERENCES}

1) Togaya, T., Suzuki, M., Tsutsumi, S. and Ida, K.: An application of pure titanium to the metal porcelain, Dent Mater J 2 (2) : 210-219, 1983.

2) Adachi, M., Mackert, Jr., J. R., Parry, E. E. and Fairhurst, C. W.: Oxide adherence and porcelain bonding to titanium and Ti-6Al-4V alloy, $J$ Dent Res 69 (6) : 1230-1235, 1990.

3) Kimura, H., Horng, C.-J., Okazaki, M. and Takahashi, J.: Oxidation effects on porcelain-titanium interface reactions and bond strength, Dent Mater J 9 (1): 91-99, 1990.

4) Nagayama, K., Izumi, T., Kikui, T., Okazaki, M. and Noguchi, H.: Porcelain-fused-to-titanium system-EPMA, ESCA studies on the titanium surface and the interface between titanium and fused porcelain-, J J Dent Mater 12 (S22) : 224-225, 1993. (in Japanese)

5) Oshida, Y. and Hashem, A.: Titanium-porcelain system part I : Oxidation and kinetics of nitrided pure titanium, simulated to porcelain firing process, Bio-Med Mater Eng 3 (4) : 185-198, 1993.

6) Ohuchi, F. S. and Kohyama, M. : Electronic structure and chemical reactions at metal-alumina and metal-aluminum nitride interfaces, J Am Ceram Soc 74 (6) : 1163-1187, 1991.

7) Authony, M. T. and Seah, M. P : XPS. Energy calibration of electron spectrometers. 1. An absolute, traceable energy calibration and the provision of atomic reference line energies, Surf Interface Anal 6 (3) : 95-106, 1984.

8) Asami, K., Hashimoto, K. and Shimodaira, S. : XPS determination of compositions of alloy surfaces and surface oxides on mechanically polished iron-chromium alloys, Corr Sci 17: 713-723, 1977.

9) Takahashi, H. and Nagayama, M.: Surface films formed on aluminum by different pretreatments, I. XPS analysis of thickness and chemical composition, J Jpn Soc Surf Finsh 36 (3) : 96-103, 1985. (in Japanese)

10) Practical Surface Analysis, 2nd ed., Vol. 1, Auger and X-ray Photoelectron Spectroscopy, Briggs, D. and Seah, M. P. Eds., John Wiley \& Sons, New York, 1990.

11) McIntyre, N. S. and Chan, T. C.: Uses of Auger electron and photoelectron spectroscopies in corrosion science, Practical Surface Analysis, 2nd ed., Vol. 1, Auger and X-ray Photoelectron Spectroscopy, Briggs, D. and Seah, M. P, Eds., John Wiley \& Sons, New York, 1990, pp. 485-529.

12) Okazaki, S. : Surface properties and surface modifications of $\mathrm{TiO}_{2}, J$ Adhesion Soc Jpn 21 (1) : 24-31, 1985. (in Japanese)

13) Phillips, R. W. : Skinner's science of dental materials, 8th ed., W. B. Saunders Co., Philadelphia, 1982, p. 504.

14) Wagner, C. D., Riggs, W. M., Davies, L. E., Moulder, J. F. and Muilenberg, G. E. : Handbook of X-ray photoelectron spectroscopy, Perkin-Elmer, Eden Prairie, Minnesota, 1979.

15) Yabe, K. : Chemical state analysis of titanium oxides by means of XPS, Progress in X-ray Analyses, Vol. 17, Agune Technical Center, Tokyo, 1986, pp. 71-80. (in Japanese)

16) Sakuhana, S., Sakaino, T. and Takahashi, K. : Glass handbook, 3rd ed., Asakura Shoten, Tokyo, 1979, pp. 694-696. (in Japanese)

17) Kimura, H., Horng, C.-J., Okazaki, M. and Takahashi, J.: Thermal compatibility of titanium-porcelain system, $J$ Osaka Univ Dent Sch 30: 43-52, 1990.

18) CRC handbook of chemistry and physics, 67th ed., Weast, R. C. ed., CRC Press, Boca Raton, Florida, 1986, pp. D50-D93. 


\title{
仮封材除去後のエナメル質および象牙質の特性 一仮封材がレジンセメントの歯質接着性に与える影響— \\ 寺田林太郎, 中島 薰, 小原雅彦, 久保田稔 \\ 岩手医科大学歯学部歯科保存学第一講座
}

この研究は, 仮封処置がレジンセメントの歯質接着性 に与える影響を検討したものである。 5 種の仮封材と 5 種のレジンセメントを実験に用いた。600本の牛歯を被 験歯として使用した。仮封処置がレジンセメントの歯質 接着性に与える影響は，仮封材により異なっていた。ュ
ージノール系, 非ユージノール系のいずれの仮封材も， レジンセメントの歯質接着性を隇少させていた。いずれ の仮封材を使用しても，エナメル質および象牙質におい て 4-META 系レジンセメントが安定した歯質接着性を 示していた。

MMA-TBB 系レジンによるエナメル質の接着における銅塩含有プライマーの効果

\author{
平 矅輔, 今井庸二 1 \\ 長崎大学歯学部歯科補綴学第一講座 \\ ${ }^{1}$ 東京医科歯科大学医用器材研究所生体機能材料部門
}

TBB 系レジンセメントの接着耐久性改善の試みとし て，エナメル質とステンレス鋼の接着におよぼす銅塩含 有プライマーの効果を検討した。牛歯エナメル質を $10 \%$ リン酸でエッチング後, 銅塩を含むアセトンプライマー で処理し, TBB 系レジンで接着した。水中での熱サイク ル試験を行った後,引張り接着強さを測定した。市販の コンポジット型レジンセメントとも比較した。銅塩の塗
布はMMA-TBBレジンによる接着強さの耐久性を全 般的に向上させたが, 2 -メタクリロイルオキシエチルコ ハク酸銅を含むプライマーを用いて，4-META/MMATBBレジンで接着した場合に最もよい耐久性が得ら れ, 市販品よりもすぐれていた。熱サイクル 2,000 回後 でも接着強さの平均值 $21 \mathrm{MPa}$, 最低值約 $12 \mathrm{MPa}$ が維持 されていた。

\section{陶材中元素の酸化チタンへの拡散 \\ 塙 隆夫, 今 政幸, 大川昭治 ${ }^{1}$, 浅岡憲三 \\ 徳島大学歯学部歯科理工学講座 \\ ${ }^{1}$ 北海道大学歯学部歯科理工学講座}

3 種類の市販チタン用焼付陶材中の元素が加熱中に酸 化チタンへどのように拡散するかを調べた。円板状に形 成し焼成した陶材上にチタンを 2 種類の厚さに真空蒸着 し, 大気中で加熱した。蒸着膜厚は, 表面アラサ計およ びエリプソメーターによって湘定した。加熱によってチ タンは酸化し, 薄い酸化チタンが陶材を覆った。この表 面およびチタンを蒸着していない陶材の表面を $\mathrm{X}$ 線光 電子分光で解析した。その結果, チタン用焼付陶材は木
ウ酸の量が従来型よりも多かった。これは，チタンに合 わせて熱膨張係数を小さくするためと考えられる。加熱 後の酸化チタン中のチタンは 3 価と 4 価の間の価数であ り, ナトリウム, カリウム, バリウムのみが加熱中に酸 化チタンに拡散した。これらの元素は酸化チタン中に混 合しているのではなく, チタンと複合酸化物を形成して いた。これらの元素の拡散は陶材とチタンとの結合に関 係していると考えられる。 